\title{
Treatment with a nonsteroidal antiinflammatory drug after calving did not improve milk production, health, or reproduction parameters in pasture-grazed dairy cows
}

\author{
S. Meier, ${ }^{\star}$ N. V. Priest, ${ }^{* 1}$ C. R. Burke, ${ }^{\star}$ J. K. Kay, ${ }^{\star}$ S. McDougall,† M. D. Mitchell,‡ C. G. Walker, ${ }^{\star}$ A. Heiser,§ \\ J. J. Loor,\# and J. R. Roche ${ }^{\star 2}$ \\ *DairyNZ Limited, Private Bag 3221, Hamilton, New Zealand 3240 \\ †Cognosco, Anexa Animal Health, PO Box 21, Morrinsville 3300, New Zealand \\ $\ddagger$ University of Queensland, Centre for Clinical Research, Royal Brisbane \& Women’s Hospital Campus, Herston, Queensland 4029, Australia \\ $\S A g R e s e a r c h$, Hopkirk Research Institute, Grasslands Research Centre, Palmerston North, New Zealand 4442 \\ \#Department of Animal Sciences, University of Illinois, Urbana 61801
}

\begin{abstract}
Previous research results have indicated an increase in pregnancy rate in pasture-grazed cows treated with a nonsteroidal antiinflammatory drug (NSAID) 3 to $4 \mathrm{wk}$ postcalving, when a high proportion of nucleated cells from within the uterus were polymorphonucleated; however, no effect on milk production was detected. It was hypothesized that this lack of effect on milk production was because the administration of the NSAID was too late after calving. The aims of the current study were to evaluate the timing of administering a propionic acid-derived NSAID (i.e., carprofen) on milk production, metabolic status, uterine health, and reproductive performance. Six-hundred and thirty-nine cows (134 primiparous and 505 multiparous) calving between July 4 and September 5, 2012, in 2 herds (herd 1: $\mathrm{n}=228$; herd $2: \mathrm{n}=411$ ) were enrolled. Using a randomized block design, cows were allocated to 1 of 3 treatment groups as they calved: (1) no treatment (control; $\mathrm{n}=$ 221), (2) NSAID administered on d 1, 3, and 5 postcalving (early; $\mathrm{n}=214$ ), and (3) NSAID administered on d 19, 21, and 23 postcalving (late; $\mathrm{n}=204$ ). Milk production and composition, and body condition were determined weekly. Blood was sampled at 4 time points (1 precalving and 3 postcalving) to determine the effects of treatment on indicators of metabolic health and energy status. Uterine health was determined by measuring the proportion of nucleated cells that were polymorphonucleated following cytobrush sampling of the uterus between d 13 to 24 and d 30 to 49 postcalving. Irrespective of timing of application, NSAID did not affect milk production, body weight, or body
\end{abstract}

\footnotetext{
Received December 16, 2013

Accepted February 8, 2014.

${ }^{1}$ Current address: Livestock Improvement, Hamilton, New Zealand 3240 .

${ }^{2}$ Corresponding author: john.roche@dairynz.co.nz
}

condition during early lactation. Treatment with an NSAID 19 to $23 \mathrm{~d}$ postcalving increased the proportion of cows submitted for breeding during the first $3 \mathrm{wk}$ of the seasonal breeding program (control: $85 \%$, early: $83 \%$, and late: $92 \%$ ), but did not affect conception or pregnancy rates. No detectable effect of treatment on uterine health or circulating metabolites and minerals existed, although cows in the early NSAID treatment group had marginally lower serum $\beta$-hydroxybutyrate concentrations $(0.1 \mathrm{mmol} / \mathrm{L})$ than the other groups between 2 and $26 \mathrm{~d}$ in milk. In conclusion, administration of this particular NSAID at either 1 or 3 wk after calving did not improve milk production, indicators of health, or reproductive performance.

Key words: transition cow, nonsteroidal antiinflammatory drug, reproduction, health

\section{INTRODUCTION}

Cows are under significant physiological stress during the transition period (Drackley, 1999; Drackley et al., 2005; LeBlanc, 2010), with a requirement to increase the metabolic capacity of productive tissues (Bell, 1995) and a high incidence of disease occurring during this period of lactation (Overton and Waldron, 2004; Ingvartsen, 2006). The period is characterized by adjustments in nutrient fluxes from and to tissues that are facilitated by changes in peripheral tissue insulin sensitivity (Hayirli, 2006; Chagas et al., 2009; De Koster and Opsomer, 2013; Zachut et al., 2013), an uncoupling of the somatotropic axis (Lucy et al., 2009), and a peripartum proinflammatory response involving the liver (Farney et al., 2013a). Failure to transition successfully can reduce milk production, increase the size of the negative energy balance, and reduce subsequent fertility (Bertoni et al., 2008; Roche et al., 2013).

In recent years, interest has increased in the association between behavioral and metabolic indices and the incidence and severity of disease in dairy cows. Burke 
et al. (2010b) reported elevated haptoglobin and liver enzyme concentrations 4 to $6 \mathrm{wk}$ postcalving in cows diagnosed with subclinical endometritis (SCE), reflecting the liver's involvement in the inflammatory cascade. More interestingly, though, they reported differences in blood albumin concentrations precalving in cows subsequently identified with SCE; similarly, Huzzey et al. (2009) reported elevated haptoglobin concentrations before clinical signs of metritis and Huzzey et al. (2007) reported a reduction in time spent eating and DMI precalving in cows that subsequently developed metritis. These data reflect the occurrence of peripartum physiological changes before evident pathology and implicate the liver in SCE (Bertoni et al., 2008).

Because of the increasing evidence that failure to transition successfully is associated with a peripartum inflammatory state, interest in the use of nonsteroidal antiinflammatory drugs (NSAID) has increased. Interventions with NSAID have been reported to have metabolic benefits in a range of species (Bradford and Farney, 2010) and have shown promise in dairy cows in recent studies. For example, treatment of cows with salicylic acid immediately postpartum improved milk yield during the first 2 mo postcalving (Trevisi and Bertoni, 2008; Farney et al., 2013a) and improved firstservice pregnancy rates (Trevisi and Bertoni, 2008). In comparison, treatment with a propionic acid-derived NSAID (i.e., carprofen) 3 to 4 wk postcalving increased conception rates in cows categorized as having high proportions of PMNL in the uterus 2 wk postcalving (Priest et al., 2013), but did not affect milk-production variables, even though the cows with SCE had a similar reduction in milk production to that reported by Burke et al. (2010b) and McDougall et al. (2011).

We hypothesized that the timing of administration of the NSAID in previous studies was too late to elicit a milk-production response, but that application during the days immediately postcalving, as per the protocol outlined by Trevisi and Bertoni (2008) using salicylic acid, would increase milk production and have beneficial effects on reproduction. The objectives of this study were to evaluate the effect of postcalving administration of a propionic acid-derived NSAID and the timing of administration on milk production, metabolic health, and reproduction parameters in grazing dairy cows.

\section{MATERIALS AND METHODS}

The Ruakura Animal Ethics Committee (Hamilton, New Zealand) approved all animal manipulations in accordance with the New Zealand Animal Welfare Act (Ministry for Primary Industries, 1999). Two seasonal calving dairy herds (herd $1: \mathrm{n}=228$; herd $2: \mathrm{n}=411$; total: $\mathrm{n}=639$ ) managed on a single commercial farm
(Whareroa Dairy Farm, Hawera, New Zealand; 39.6 ${ }^{\circ} \mathrm{S}$, $174.3^{\circ} \mathrm{E}$ ) were enrolled. All cows calved between July 4 and September 5, 2012. The age structure was typical of commercial New Zealand dairy herds, with 134 primiparous and 505 multiparous cows; the predominant breeds represented were Holstein-Friesian and HolsteinFriesian $\times$ Jersey crossbred.

\section{Nonsteroidal Antiinflammatory Treatment}

Within each herd, cows were allocated to 1 of 3 groups as they calved within a randomized block design (control: $\mathrm{n}=221$, early: $\mathrm{n}=214$, and late: $\mathrm{n}=204$ ). All cows were restrained in the race used for blood sampling. Control cows were not treated, whereas cows allocated to the early and late NSAID treatments received 3 subcutaneous treatments of $1.4 \mathrm{mg} / \mathrm{kg}$ of BW of the NSAID carprofen (Carprieve LA; Norbrook Ltd., Auckland, New Zealand). The early treatment group received the Carprieve LA injections on 1,3 , and 5 DIM and the late treatment group at 19, 21, and 23 DIM. Body weight was determined before calving.

\section{Feeding Management}

Nonlactating transition cows, fresh cows (i.e., 1-4 DIM), and lactating cows within each treatment were managed as separate groups. Cows were rotationally grazed as described by Roche et al. (2005). Briefly, cows rotated around defined sections of the grazing area (paddocks) and did not return to a grazed area until an average of 2 to 2.5 leaves had regrown on the ryegrass plants (Lolium perenne L.). As the seasonalcalving period extends from winter to spring and pasture growth rates increase accordingly (Roche et al., 2009), area allocated per cow increased with time, from approximately $35 \mathrm{~m}^{2} /$ cow 3 wk before calving to approximately $165 \mathrm{~m}^{2} / \mathrm{cow} 6$ to 8 wk postcalving.

The rising plate meter (Farmworks, Palmerston North, New Zealand) technique described previously by Roche et al. (2005) was used to estimate the mass of pasture before and after grazing on $4 \mathrm{~d}$ each week. Pasture assessments were undertaken from approximately 2 wk pre- to 6 wk postcalving. Pregrazing and postgrazing pasture mass was 2,800 \pm 65 and $1,250 \pm 32 \mathrm{~kg}$ of DM per ha (measured to ground level, mean \pm SEM), respectively, for the nonlactating cows and 2,850 \pm 40 and $1,650 \pm 74 \mathrm{~kg}$ of $\mathrm{DM} / \mathrm{ha}$, respectively, for lactating cows. Pasture silage was offered to the nonlactating cows and either pasture silage or corn silage was offered to lactating cows as deemed necessary (i.e., insufficient pasture available) by the farm manager.

Pasture was sampled to grazing height from paddocks to be grazed; these, along with samples of supple- 
ments offered, were bulked weekly and every 2 wk for DM and quality analyses, respectively. Weekly samples were dried in triplicate at $95^{\circ} \mathrm{C}$ for $48 \mathrm{~h}$ to determine DM content (\%). For feed quality assessment, samples were dried at $60^{\circ} \mathrm{C}$ for $72 \mathrm{~h}$, ground to pass through a 2.0-mm sieve (Christy Lab Mill; Christy Turner Ltd., Suffolk, UK), and analyzed by wet chemistry (Ankom Technology method 3; Dairy One, Ithaca, NY). The nutritional analyses of feeds offered are presented in Table 1.

\section{Milk Production, BW, and BCS}

Milk yield was recorded on $1 \mathrm{~d}$ each week and a representative p.m. and a.m. sample collected for fat and $\mathrm{CP}$ determination [MilkoScan (Foss Electric A/S, Hillerød, Denmark); LIC, Hamilton, New Zealand]. Body condition was determined weekly on a 10-point scale, where a score of 1 is emaciated and 10 is obese (Roche et al., 2004). Cow BW was recorded precalving (June 26) and 6 to 8 wk postcalving.

Table 1. Mean ( \pm SEM in parentheses) nutrient composition (\% of DM, unless otherwise stated), macro- and trace-mineral $(\mathrm{mg} / \mathrm{kg}$ of $\mathrm{DM})$ concentration, DCAD $(\mathrm{mEq} / 100 \mathrm{~g}$ of $\mathrm{DM}), 24$-h in vitro total digestibility (IVTD), 24-h NDF digestibility (NDFD; \% of NDF), and DM (\% of fresh matter) of feeds offered throughout the experiment

\begin{tabular}{lccc}
\hline Item & Pasture & $\begin{array}{c}\text { Pasture } \\
\text { silage }\end{array}$ & $\begin{array}{c}\text { Corn } \\
\text { silage }\end{array}$ \\
\hline CP & $26.9(0.88)$ & 17.9 & 13.4 \\
ADIN, \% of CP & $1.3(0.46)$ & 3.4 & 1.2 \\
NDIN, \% of CP & $8.2(0.37)$ & 5.3 & 1.7 \\
ADF & $28.6(1.03)$ & 49.3 & 38.7 \\
NDF & $48.3(1.10)$ & 65.1 & 57.2 \\
Lignin & $4.5(0.25)$ & 8.5 & 4.7 \\
NFC & $16.6(1.45)$ & 6.0 & 13.6 \\
Starch & $0.38(0.04)$ & 0.7 & 9.4 \\
Crude fat & $5.0(0.24)$ & 7.9 & 5.7 \\
Ash & $11.4(0.41)$ & 8.4 & 11.8 \\
Ca & $0.43(0.01)$ & 0.42 & 0.4 \\
Cl & $1.6(0.05)$ & 0.48 & 1.17 \\
Mg & $0.23(0.01)$ & 0.12 & 0.21 \\
P & $0.44(0.02)$ & 0.17 & 0.26 \\
K & $3.3(0.15)$ & 0.97 & 1.79 \\
Na & $0.48(0.09)$ & 0.14 & 0.42 \\
S & $0.38(0.01)$ & 0.25 & 0.19 \\
Fe & $270(47.8)$ & 1,610 & 2,550 \\
Zn & $41.0(2.59)$ & 35.0 & 44.0 \\
Cu & $11.5(0.34)$ & 15.0 & 10.0 \\
Mn & $88.3(5.90)$ & 83.0 & 101.0 \\
Mo & $0.68(0.04)$ & 0.8 & 0.4 \\
DCAD & $38.3(2.51)$ & 2.0 & 19.0 \\
IVTD & $92.7(0.42)$ & 75.0 & 74.0 \\
NDFD & $85.0(1.00)$ & 61.0 & 54.0 \\
DM, ${ }^{1} \%$ & $17(3.5)$ & 25 & 32 \\
\hline I & & & \\
\hline
\end{tabular}

${ }^{1}$ Weekly samples were dried in triplicate at $95^{\circ} \mathrm{C}$ for $48 \mathrm{~h}$ to determine the DM content (\%).

\section{Blood Samples and Analyses}

Blood was serially sampled via coccygeal venipuncture at approximately $0800 \mathrm{~h}$ on 4 occasions; sample 1 was between 33 and $4 \mathrm{~d}$ before calving, sample 2 between 2 and $26 \mathrm{~d}$ postcalving, sample 3 between 27 and $41 \mathrm{~d}$ postcalving, and sample 4 between 42 and $51 \mathrm{~d}$ postcalving. Blood was collected into 2 evacuated blood tubes, one containing lithium heparin as an anticoagulant and the other no anticoagulant (Vacutainer; Becton, Dickinson and Co., Franklin Lakes, NJ). Heparinized samples were placed in iced water immediately following collection; samples collected in serum tubes were allowed to clot overnight. Serum and plasma were aspirated following centrifugation $(1,500 \times g$ for $12 \mathrm{~min}$ at $4^{\circ} \mathrm{C}$ ) and samples were stored in duplicate at $-20^{\circ} \mathrm{C}$.

Serum and plasma samples were submitted to Gribbles Veterinary Pathology Ltd. (Hamilton, New Zealand) for analysis. Samples were analyzed for indicators of protein status: albumin $(\mathrm{g} / \mathrm{L}$; bromocresol green reaction at $\mathrm{pH} 4.1)$, total protein $(\mathrm{g} / \mathrm{L}$; biuret reaction method), and globulin $(\mathrm{g} / \mathrm{L}$; total protein minus albumin); metabolic status: NEFA (mmol/L; commercial kit using the acyl CoA synthase, acyl-CoA oxidase method; Wako Pure Chemical Industries Ltd., Osaka, Japan) and BHBA (mmol/L; dehydrogenase assay; Wako Pure Chemical Industries Ltd.); mineral status: $\mathrm{Mg}$ (mmol/L; xylidyl blue reaction) and $\mathrm{Ca}$ (mmol/L; o-cresolphthalein complexone method); and liver function: glutamate dehydrogenase (GDH; $\mathrm{IU} / \mathrm{L}$; catalyzing activity of NADH-dependent conversion of $\alpha$-ketoglutarate to glutamate) and aspartate aminotransferase (AST; IU/L; catalyzing activity of transamination of L-aspartate to oxaloacetate). All assays were colorimetric and performed at $37^{\circ} \mathrm{C}$ with a Roche Modular P800 analyzer (Roche Diagnostics, Indianapolis, IN), using Roche Modular commercial kits. The intra- and interassay coefficients of variation for all assays were $<5 \%$.

\section{Sampling of the Reproductive Tract}

Endometrial Cytology. Uterine endometrial cytology samples were collected postpartum as described by Burke et al. (2010b). Briefly, the vulva of the cow was cleaned with a paper towel and a double-guarded, modified AI pipette was passed through the cervix and into the uterus. A stylet with a cytology brush attached (Pap endocervical sample brush; EBOS Group Ltd., Christchurch, New Zealand) was used to collect a sample from the uterine wall. The stylet was then retracted into the AI sheath and all sampling equipment removed from the cow. The brush was rolled onto a microscope slide and its contents air dried. The dry slides were 
stained using Diff-Quick (Dade Behring Inc., Newark, DE). Samples were obtained at 2 time points postcalving: between 13 to $24 \mathrm{~d}$ postcalving and between 30 to $49 \mathrm{~d}$ postcalving.

A single veterinary pathologist from Gribbles Veterinary Pathology Laboratory determined the proportion of PMNL in the swab. Areas of each slide that contained small clusters of epithelial cells ( 5 to 20 per cluster) were preferentially selected and all identifiable nucleated cells counted. On average, 445 cells were counted per slide (SEM: 2.8 cells; $\leq 200$ cells counted on 35 slides $(2.8 \%)$ and $\geq 500$ cells were counted on 26 slides $(2.1 \%)$. A random subsample of slides was checked by an experienced veterinary pathologist. Operator accuracy was $97 \%$ (SEM: $1.3 \% ; \mathrm{n}=48$ ). Of 1,253 slides, $5.2 \%$ of slides contained red blood cells and 5 slides were excluded for insufficient cells $(0.004 \%$ failure rate).

Vaginal Discharge. On the completion of endometrial sampling, vaginal content was sampled using a Metricheck device (Simcro Tech Ltd., Hamilton, New Zealand; http://www.simcro.com/Product_Range/ Specialised_Items/index.html); this device consists of a $40-\mathrm{mm}$ diameter hemisphere of silicon attached to a 500-mm-long stainless steel rod. The vaginal content was scored ( 0 being no sample, 1 being clear mucus, and 5 being purulent pus; McDougall et al., 2007).

Mating and Pregnancy Diagnosis. As the grazing system was seasonal, mating management commenced on a set calendar date (planned start of mating: October 9, 2012). All cows detected in estrus in the first 6 wk (i.e., October 9 to November 16) were bred by AI, with natural mating by comingled bulls occurring, thereafter, for a further 6 wk (i.e., November 17 to December 24). Evaluations of pregnancy status and fetal aging to confirm conception dates were undertaken 72 , 101, and $125 \mathrm{~d}$ after the planned start of mating.

\section{Statistical Analyses}

Disease Definitions. Cows were identified with purulent vaginal discharge when the vaginal mucus was scored as 2, 3, 4, or 5 using the Metricheck device, and defined as having normal vaginal discharge when scored 0 and 1 (McDougall et al., 2007). The PMNL threshold for classifying cows with SCE was $\geq 14 \%$ at the first cytological examination or $\geq 7 \%$ at the second cytological examination (Priest et al., 2013). Using these thresholds for PMNL percentage, cows were classified as low-low $(<14$ and $<7 \%$ PMNL), low-high $(<14$ and $\geq 7 \%$ PMNL), high-low ( $\geq 14$ and $<7 \%$ PMNL, representing the self-cure rate), or high-high ( $\geq 14$ and $\geq 7 \%$ PMNL, representing persistent SCE).
Effects of Treatment. Cows treated with antibiotics for mastitis or other non-uterine diseases $(\mathrm{n}=$ 42; control: $\mathrm{n}=11$, early: $\mathrm{n}=12$, and late: $\mathrm{n}=19$ ) were excluded from subsequent analyses. All analyses were undertaken using GenStat 14 (VSN International Ltd., Hemel Hempstead, UK; Payne et al., 2011), with the predicted means adjusted for weightings (average weightings are represented in parentheses) applied to age group [2 yr (19\%); 3+ yr (81\%)], herd [herd 1 (37\%); herd $2(63 \%)$ ], and calving week [before July 17 (12\%); July 17 to July 23 (20\%); July 24 to July 30 (20\%); July 31 to August 6 (15.3\%); August 7 to August 13 (10\%); August 14 to August 20 (6.7\%); August 21 to August 27 (5.5\%); August 28 to September 4 $(10.5 \%)]$. Where the comparison was undertaken before NSAID infusion for the late treatment, the comparison was control + late compared with early; otherwise, all 3 treatments were included (control, late, and early). Variance is presented as the standard error of the difference, with statistical significance defined when $P \leq$ 0.05 .

Milk Production, $B W$, and $B C S$. Effect of treatment on weekly milk production to wk 6 postcalving, BW at 6 to 8 wk postcalving, and BCS between wk 2 and wk 6 postcalving was analyzed using REML variance components analysis. The statistical model for milk production variables included age group, calving week, herd, milk sample (a.m. or p.m.), lactation week (1-6), calving week $\times$ lactation week (1-6), treatment, age group $\times$ treatment, and lactation week $(1-6) \times$ treatment. The random effects were cow and lactation week (1-6) within cow with a compound symmetry covariance structure. The statistical model for BW and BCS included age group, calving week, herd, treatment, and age group $\times$ treatment, with cow as the random effect.

Blood Analyses. The effects of NSAID treatment on metabolite concentrations were analyzed using REML variance components analysis following logarithmic transformation for BHBA, NEFA, AST, and GDH. The statistical model included age group, calving week, treatment, age group $\times$ treatment, and herd as fixed effects, cow as the random effect, and included a covariate (precalving sample).

Uterine and Vaginal Parameters. The effect of treatment on uterine (PMNL percentage) and vaginal (Metricheck score) parameters was analyzed using REML variance components analysis. Angular transformation of PMNL percentage was used for analyses, but the raw means are presented to help with interpretation, as the conclusions were similar. Sixty cows did not have any PMNL percentage data within the date ranges outlined and were, therefore, excluded from the analyses. The statistical model included age 
Table 2. Yield of milk and milk components, milk composition, BW, and BCS in untreated cows (control) or those treated with a nonsteroidal antiinflammatory drug (1.4 $\mathrm{mg}$ of carprofen $/ \mathrm{kg}$ of BW) on $\mathrm{d} 1,3$, and 5 postcalving (early) or d 19, 21, and 23 postcalving (late)

\begin{tabular}{|c|c|c|c|c|c|}
\hline \multirow[b]{2}{*}{ Item } & \multicolumn{3}{|c|}{ Treatment } & \multirow[b]{2}{*}{$\mathrm{SED}^{1}$} & \multirow[b]{2}{*}{$P$-value } \\
\hline & Control & Early & Late & & \\
\hline \multicolumn{6}{|c|}{ Milk parameter (first $6 \mathrm{wk}$ of lactation) } \\
\hline Milk weight, $\mathrm{kg} / \mathrm{cow}$ per day & 20.95 & 21.15 & 20.82 & 0.432 & 0.60 \\
\hline Fat yield, $\mathrm{kg} / \mathrm{cow}$ per day & 0.93 & 0.94 & 0.93 & 0.017 & 0.81 \\
\hline $\mathrm{CP}$ yield, $\mathrm{kg} / \mathrm{cow}$ per day & 0.74 & 0.75 & 0.73 & 0.013 & 0.50 \\
\hline Fat, $\%$ & 4.58 & 4.56 & 4.58 & 0.078 & 0.96 \\
\hline CP, \% & 3.59 & 3.57 & 3.56 & 0.029 & 0.60 \\
\hline \multicolumn{6}{|l|}{$\mathrm{BW}, \mathrm{kg}$} \\
\hline Precalving $^{2}$ & 474 & 482 & 470 & 70.7 & - \\
\hline Postcalving $^{3}$ & 428 & 418 & 418 & 7.1 & 0.27 \\
\hline \multicolumn{6}{|l|}{ BCS } \\
\hline Precalving $^{4}$ & 4.4 & 4.4 & 4.4 & 0.39 & - \\
\hline Postcalving ${ }^{5}$ & 4.2 & 4.1 & 4.2 & 0.05 & 0.56 \\
\hline \multicolumn{6}{|c|}{${ }^{1} \mathrm{SE}$ of the difference. } \\
\hline \multirow{4}{*}{\multicolumn{6}{|c|}{$\begin{array}{l}{ }^{2} \text { Approximately } 1 \text { to } 10 \text { wk precalving (June 26, 2012). } \\
{ }^{3} \text { Approximately } 6 \text { to } 8 \text { wk postcalving (based on calving date either on August } 16 \text { or October 3, 2012). } \\
{ }^{4} \text { Approximately } 1 \text { to } 10 \text { wk precalving (June 26, 2012). }\end{array}$}} \\
\hline & & & & & \\
\hline & & & & & \\
\hline${ }^{5}$ Approximately 6 wk postcalvi & & & & & \\
\hline
\end{tabular}

group, calving week, herd, treatment, and age group $\times$ treatment, as fitted terms. For uterine and vaginal parameters measured between d 13 and 24 postcalving, the treatment comparison was control + late and early as fitted terms. For uterine and vaginal parameters measured between d 30 and 49 postcalving, the treatment comparison included control, early, and late as fitted terms.

Reproductive Outcomes. Eight cows had no pregnancy data collected and were excluded from these analyses. Submission, conception, and pregnancy rates were analyzed using binomial regression analysis with a logit link function, with age group, calving week, herd, treatment, and age group $\times$ treatment as fitted terms.

\section{RESULTS AND DISCUSSION}

The objective of this experiment was to investigate the effect of administering a propionic acid-derived NSAID (i.e., carprofen) postcalving on production, metabolic health, and subsequent fertility in transition dairy cows grazing fresh pasture. Previous research has indicated positive effects of salicylic acid treatment in the $5 \mathrm{~d}$ immediately postcalving on milk production and reproduction variables (Trevisi and Bertoni, 2008; Farney et al., 2013a,b). The effects of derivatives of propionic acid on milk production and reproduction have not been widely reported, although carprofen has been reported to reduce some of the inflammatory effects of mastitis (Vangroenweghe et al., 2005). Recently, carprofen was reported to have a positive effect on pregnancy rates in cows detected with high uterine PMNL percentage (Priest et al., 2013), although treatment did not affect milk production. It was hypothesized that the lack of effect on production responses in that study was because of a delay in administering the NSAID until $3 \mathrm{wk}$ postcalving and that administering earlier in lactation would result in milk-production benefits along with the improvements in reproduction reported by Priest et al. (2013).

\section{Milk Production, BCS, and BW}

Administering NSAID to lactating dairy cows did not affect milk production or BCS and BW change in the current experiment, irrespective of the timing of delivery. Average milk production over the first $6 \mathrm{wk}$ of lactation was not affected (Table $2 ; P=0.60$ ); also, no week by treatment interaction (Figure $1 ; P=0.21$ ) and no effect of treatment on milk composition (Figure 1) or the yield of milk components (Table 2) were detected. General agreement exists that cows with an elevated PMNL percentage have lower milk yields than unaffected cows. (Burke et al., 2010b) and McDougall et al. (2011) reported reduced milk production in cows with elevated uterine PMNL percentage $(\sim 1 \mathrm{~kg}$ of milk/d), which is consistent with the numerical difference in milk production reported in the study of Priest et al. (2013). Despite this apparent inflammatory-mediated reduction in milk production in previous work, no such association existed between uterine PMNL percentage and milk production evident in the current study. Furthermore, the data presented here and data from Priest et al. (2013) indicate that carprofen administration 

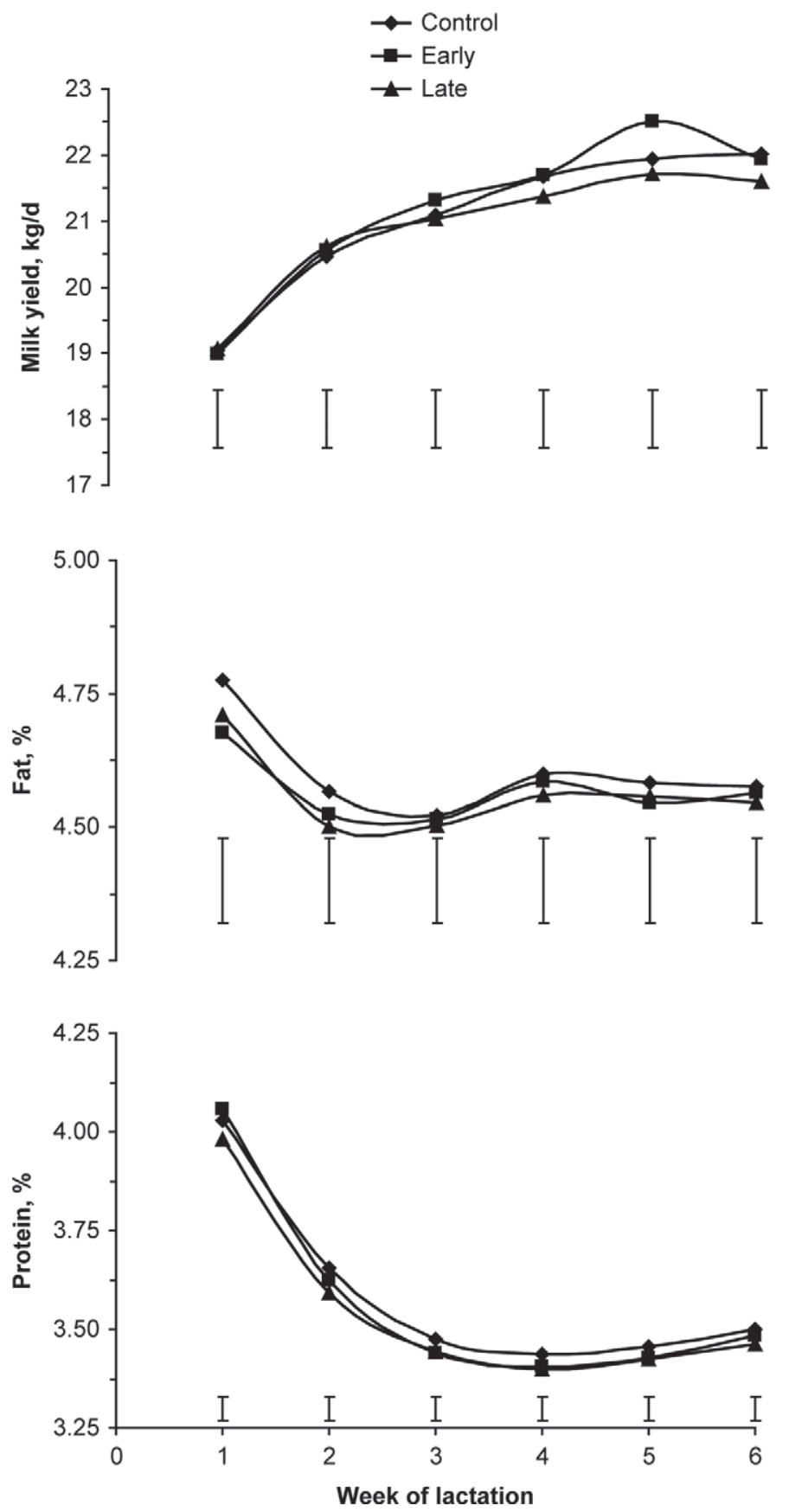

Figure 1. Milk yield and fat and protein percentage in untreated cows (control) or those treated with a nonsteroidal antiinflammatory drug (1.4 $\mathrm{mg}$ of carprofen $/ \mathrm{kg}$ of BW) on $\mathrm{d} 1,3$, and 5 postcalving (early) or d 19,21, and 23 postcalving (late). Vertical bars represent $2 \times$ SE of the difference.

either during the colostrum period or $3 \mathrm{wk}$ postcalving does not improve milk production. This is inconsistent with the results reported from administering salicylic acid during the first week postcalving (Trevisi and Bertoni, 2008; Farney et al., 2013a,b), wherein ECM production was greater in treated cows relative to untreated controls. This may reflect differences in the milk production and, therefore, the metabolic stress the cows are subjected to, or differences in the mode of action of different NSAID.

The lack of a treatment effect on milk production was consistent with a failure of treatment to influence measures of energy balance. Body weight and BCS 6 to 8 wk postcalving were not different among the 3 treatments (Table 2) and no effect of treatment on plasma NEFA concentrations was detected (Table 3). The effects of NSAID administration in early lactation on energy balance are inconsistent. In previous studies in grazing cows (Burke et al., 2010b; McDougall et al., 2011), the postcalving inflammation associated with the PMNL percentage was not associated with either BCS loss or postcalving blood NEFA concentration, although Priest et al. (2013) reported greater plasma NEFA concentrations on the day of calving in cows with high uterine PMNL percentage 2 wk later. In contrast, Farney et al. (2013a) reported a more severe negative energy balance and greater NEFA and BHBA concentrations 2 to 3 wk postcalving, and greater hepatic lipidosis on d 4 of lactation in cows treated with sodium salicylate during the first $7 \mathrm{~d}$ of lactation. No effect of treatment on liver triglyceride concentration was detected at $3 \mathrm{wk}$ postcalving, but NEFA and BHBA concentrations were still greater in NSAID-treated cows. Further research is required to investigate the reasons for the inconsistent effects of NSAID on milk production and energy balance, with a need to focus particularly on the effect of NSAID type and dose, timing of administration, and cow milk yield (i.e., production system and genetics) to better understand the reasons for these inconsistencies.

\section{Metabolic Health}

The results presented in Table 3 indicate very little effect of treatment on indices of metabolic health. Burke et al. (2010b) reported lower plasma albumin concentrations pre- and postcalving, elevated AST and GDH concentrations from 2 wk postcalving, and elevated blood haptoglobin 4 wk postcalving in cows that had high PMNL percentage 2 to 6 wk postcalving. Similarly, Green et al. (2011) and Priest et al. (2013) reported a reduction in plasma albumin concentrations in cows with SCE. These data were hypothesized to reflect a peripartum inflammation in cows that presented subsequently with liver dysfunction and that this peripartum inflammation or the liver dysfunction, or both, were hypothesized to predispose cows to SCE. If this association between SCE and albumin, AST, and GDH was causative, treatment with NSAID should improve these parameters. In the present study, however, treatment with an NSAID 1 to $5 \mathrm{~d}$ postcalving 
Table 3. Mean concentrations of blood metabolites reflective of protein, energy, and mineral status, and liver function at 3 time points during early lactation in untreated cows (control) or those treated with a nonsteroidal antiinflammatory drug (1.4 mg of carprofen/ $\mathrm{kg}$ of BW) on d 1,3, and 5 postcalving (early) or d 19, 21, and 23 postcalving (late) ${ }^{1}$

\begin{tabular}{|c|c|c|c|c|c|}
\hline \multirow[b]{2}{*}{ Item } & \multicolumn{3}{|c|}{ Treatment } & \multirow[b]{2}{*}{$\mathrm{SED}^{2}$} & \multirow[b]{2}{*}{$P$-value } \\
\hline & Control & Early & Late & & \\
\hline \multicolumn{6}{|l|}{ DIM 2-26 } \\
\hline Total protein, $\mathrm{g} / \mathrm{L}$ & 66.9 & 66.9 & & 0.46 & 0.95 \\
\hline Albumin, $\mathrm{g} / \mathrm{L}$ & 34.5 & 34.4 & & 0.30 & 0.91 \\
\hline Globulin, g/L & 32.5 & 32.4 & & 0.31 & 0.84 \\
\hline Albumin-to-globulin ratio & 1.09 & 1.08 & & 0.016 & 0.83 \\
\hline $\log _{10}$ NEFA, mmol/L & $-0.196(0.74)$ & $-0.210(0.72)$ & & 0.0200 & 0.51 \\
\hline $\log _{10} \mathrm{BHBA}, \mathrm{mmol} / \mathrm{L}$ & $0.030(1.19)$ & $-0.002(1.09)$ & & 0.0144 & $<0.05$ \\
\hline $\mathrm{Mg}, \mathrm{mmol} / \mathrm{L}$ & 0.78 & 0.78 & & 0.013 & 0.85 \\
\hline $\mathrm{Ca}, \mathrm{mmol} / \mathrm{L}$ & 2.24 & 2.25 & & 0.016 & 0.54 \\
\hline $\log _{10} \mathrm{AST}^{3}{ }^{3} \mathrm{IU} / \mathrm{L}$ & $1.91(83.2)$ & $1.92(85.4)$ & & 0.008 & 0.20 \\
\hline $\log _{10} \mathrm{GDH},{ }^{4} \mathrm{IU} / \mathrm{L}$ & $1.30(25.2)$ & $1.31(28.9)$ & & 0.024 & 0.44 \\
\hline \multicolumn{6}{|l|}{ DIM $27-41$} \\
\hline Total protein, g/L & 70.8 & 70.8 & 69.5 & 0.52 & $<0.05$ \\
\hline Albumin, $\mathrm{g} / \mathrm{L}$ & 35.3 & 34.7 & 34.4 & 0.34 & $<0.05$ \\
\hline Globulin, g/L & 35.6 & 36.1 & 35.2 & 0.52 & 0.25 \\
\hline Albumin-to-globulin ratio & 1.02 & 0.99 & 1.00 & 0.018 & 0.29 \\
\hline $\log _{10}$ NEFA, mmol/L & $-0.28(0.62)$ & $-0.28(0.62)$ & $-0.26(0.65)$ & 0.025 & 0.65 \\
\hline $\log _{10} \mathrm{BHBA}, \mathrm{mmol} / \mathrm{L}$ & $0.01(1.12)$ & $0.02(1.20)$ & $0.03(1.23)$ & 0.017 & 0.59 \\
\hline $\mathrm{Mg}, \mathrm{mmol} / \mathrm{L}$ & 0.83 & 0.83 & 0.82 & 0.014 & 0.72 \\
\hline $\mathrm{Ca}, \mathrm{mmol} / \mathrm{L}$ & 2.24 & 2.22 & 2.21 & 0.017 & 0.33 \\
\hline $\log _{10}$ AST, IU/L & $1.91(82.9)$ & $1.91(82.7)$ & $1.89(79.0)$ & 0.008 & 0.06 \\
\hline $\log _{10} \mathrm{GDH}, \mathrm{IU} / \mathrm{L}$ & $1.30(25.0)$ & $1.29(25.2)$ & $1.26(21.2)$ & 0.025 & 0.24 \\
\hline \multicolumn{6}{|l|}{ DIM $42-51$} \\
\hline Total protein, $\mathrm{g} / \mathrm{L}$ & 72.6 & 73.3 & 72.3 & 0.49 & 0.13 \\
\hline Albumin, g/L & 35.8 & 35.9 & 35.6 & 0.33 & 0.67 \\
\hline Globulin, g/L & 36.9 & 37.3 & 36.8 & 0.54 & 0.55 \\
\hline Albumin-to-globulin ratio & 0.99 & 0.99 & 0.99 & 0.019 & 0.99 \\
\hline $\log _{10} \mathrm{NEFA}, \mathrm{mmol} / \mathrm{L}$ & $-0.39(0.51)$ & $-0.35(0.56)$ & $-0.34(0.56)$ & 0.026 & 0.13 \\
\hline $\log _{10} \mathrm{BHBA}, \mathrm{mmol} / \mathrm{L}$ & $-0.04(1.00)$ & $-0.05(0.98)$ & $-0.01(1.05)$ & 0.017 & 0.13 \\
\hline $\mathrm{Mg}, \mathrm{mmol} / \mathrm{L}$ & 0.81 & 0.81 & 0.79 & 0.015 & 0.47 \\
\hline $\mathrm{Ca}, \mathrm{mmol} / \mathrm{L}$ & 2.26 & 2.25 & 2.26 & 0.016 & 0.72 \\
\hline $\log _{10} \mathrm{AST}, \mathrm{IU} / \mathrm{L}$ & $1.93(87.8)$ & $1.94(89.2)$ & $1.92(85.1)$ & 0.010 & 0.38 \\
\hline $\log _{10}$ GDH, IU/L & $1.33(29.0)$ & $1.35(30.1)$ & $1.30(22.8)$ & 0.028 & 0.29 \\
\hline
\end{tabular}

${ }^{1}$ Back-transformed data are presented in parentheses where appropriate.

${ }^{2} \mathrm{SE}$ of the difference.

${ }^{3} \mathrm{AST}=$ aspartate aminotransferase

${ }^{4} \mathrm{GDH}=$ glutamate dehydrogenase.

did not affect the concentrations of albumin, globulin, total protein, AST, or GDH in blood in early lactation, indicating a failure of treatment to influence the indicators of inflammatory state or liver function measured. Although also no effect of treatment on blood NEFA concentration existed, BHBA concentration was lower in the early NSAID cows during d 2 to 26 postcalving, possibly indicating an increased capacity of the liver to oxidize FA, but the effect was small $(0.1 \mathrm{mmol} / \mathrm{L})$. In comparison, administering the NSAID 19 to $23 \mathrm{~d}$ postpartum lowered $(P=0.06)$ circulating concentrations of AST, a change similar in scale to the effect reported by Priest et al. (2013). Paradoxically, however, total protein and albumin concentrations were lower in late NSAID cows during this time. This result is not consistent with improved hepatic function.
Limited data are available on the effect of administering an NSAID in early lactation on the concentration of either positive or negative acute-phase proteins. Bertoni et al. (2004) reported a reduction in the concentration of positive acute-phase proteins in NSAID-treated cows, most notably haptoglobin and ceruloplasmin. This appears at odds with the lower albumin concentration evident in the current study. From the collective data, the effect of the peripartum inflammation or the effect of alleviating said inflammation through NSAID administration on liver function is not clear and is probably complicated by other physiological adjustments. For example, Farney et al. (2013a) discussed the apparent paradox of negative effects of inflammation in a normal state alongside the apparently negative effects of alleviating early lactation inflammation in the 
transition cow. Greater insulin sensitivity and hypoglycemia, coupled with increased lipolysis, ketogenesis and hepatic lipidosis occurred in NSAID-treated cows in their study; Bertoni et al. (2004) also reported a more severe negative energy balance and greater incidence of metritis in NSAID-treated cows, although milk production and overall reproductive performance were improved. Farney et al. (2013a) hypothesized that, because the early lactation insulin resistance was, at least in part, induced by inflammation, it may be a protective mechanism against hypoglycemia induced by the increased lactational demands of the high-production dairy cow. The hypothesis that peripartum inflammation is, in fact, a homeorhetic adaptation to increased milk production (Farney et al., 2013a) is consistent with other physiological adaptations that have been reported to have occurred in support of milk production. For example, Chagas et al. (2009) reported greater insulin resistance and Lucy et al. (2009) reported greater uncoupling of the somatotropic axis in early lactation
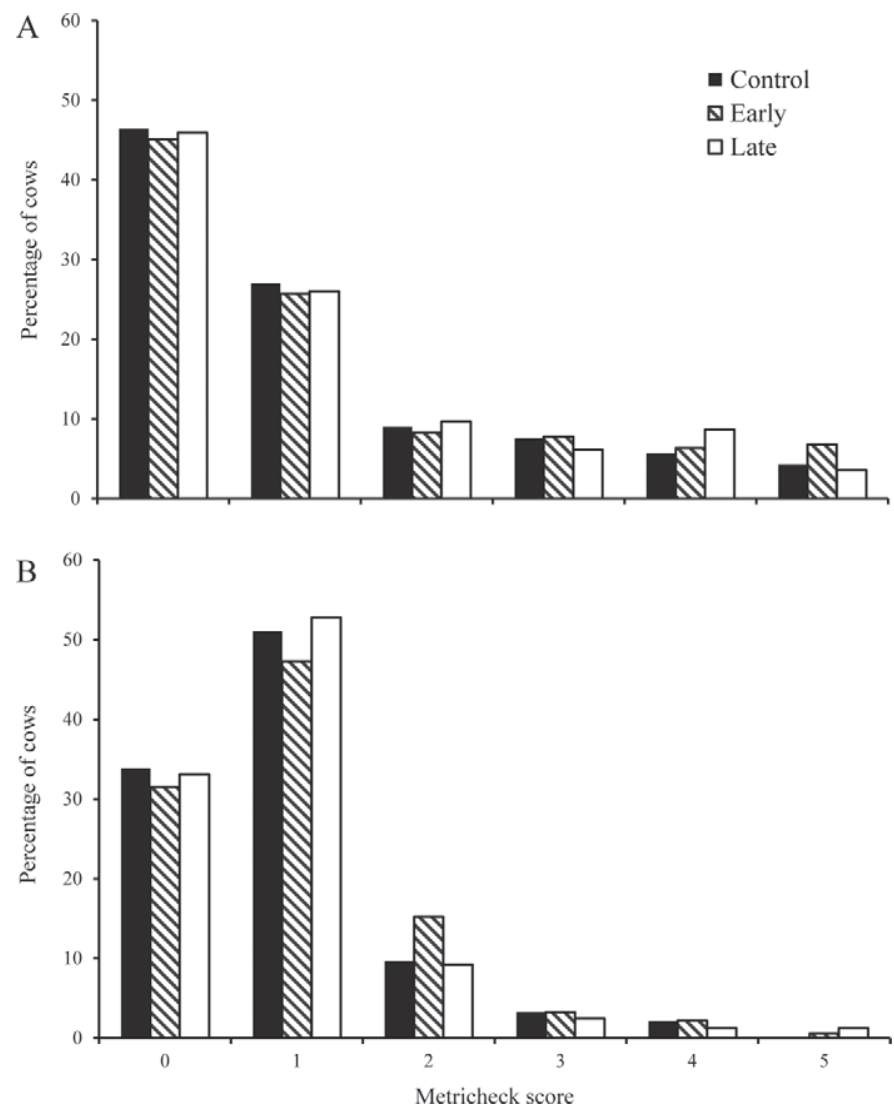

Figure 2. Frequency distribution of Metricheck (Simcro Tech Ltd., Hamilton, New Zealand) scores (0 to 5) at (A) 13 to 24 and (B) 30 to $49 \mathrm{~d}$ postcalving in dairy cows left untreated (control) or treated with a nonsteroidal antiinflammatory drug (1.4 $\mathrm{mg}$ of carprofen $/ \mathrm{kg}$ of BW) on d 1,3 , and 5 postcalving (early) or d 19, 21, and 23 postcalving (late).
Table 4. Percentage of nucleated cells in a uterine cytology sample that were classified as PMNL ${ }^{1}$ and the average Metricheck (Simcro Tech Ltd., Hamilton, New Zealand) score ${ }^{2}$ of vaginal fluid in untreated cows (control) or those treated with a nonsteroidal antiinflammatory drug (1.4 mg of carprofen $/ \mathrm{kg}$ of BW) on $\mathrm{d} 1,3$, and 5 postcalving (early) or d 19,21, and 23 postcalving (late) ${ }^{3}$

\begin{tabular}{lccccc}
\hline & \multicolumn{3}{c}{ Treatment } & & \\
\cline { 2 - 4 } Item & Control & Early & Late & SED $^{4}$ & $P$-value \\
\hline DIM 13-24 & & & & & \\
$\quad$ PMNL, \% & 36.4 & 36 & & 2.61 & 0.87 \\
Metricheck score & 1.1 & 1.2 & & 0.13 & \\
DIM 23-39 & & & & & \\
PMNL, \% & 10.7 & 12.8 & 9.9 & 1.9 & 0.29 \\
Metricheck score & 0.91 & 1.06 & 0.94 & 0.1 & \\
\hline
\end{tabular}

${ }^{1}$ The PMNL threshold for classifying cows with subclinical endometritis was $\geq 14 \%$ at the first cytological examination or $\geq 7 \%$ at the second cytological examination (Priest et al., 2013).

${ }^{2}$ Cows were identified with purulent vaginal discharge when the vaginal mucus was scored as $2,3,4$, or 5 , and defined as having normal vaginal discharge when scored 0 and 1 (McDougall et al., 2007).

${ }^{3}$ Samples were collected twice during early lactation.

${ }^{4} \mathrm{SE}$ of the difference.

in dairy cows that had been selected for greater milk production. Further support for this hypothesis was presented by Jiang et al. (2005), who reported no uncoupling of the somatotropic axis in beef cattle, linking this particular physiological change to genetic selection for milk production. Both of these adaptations are a result of relatively recent genetic selections (Lucy et al. 2009) and would result in greater glucose production and glucose sparing from peripheral tissues, thereby ensuring euglycemia while facilitating greater milk production. It is plausible, and is certainly supported by the effect of NSAID on insulin resistance reported by Farney et al. (2013a), that the periparturient inflammation is also a part of the homeorhetic adaptations acquired through genetic selection for milk production. Such an association may also explain, in part, the negative genetic correlation between milk production and health (Uribe et al., 1995).

An extension of the hypothesis that the peripartum inflammation is a necessary component of homeorhetic adaptations to a lactational state is that the use of NSAID treatment too early in lactation could have detrimental, rather than beneficial, effects on animal physiology. The more severe negative energy balance, the greater NEFA and BHBA concentrations in blood, and the increase in hepatic lipidosis in NSAID-treated cows reported by Farney et al. (2013a) all support this assertion. However, a subsequent publication from the same team (Farney et al., 2013b) identified a $21 \%$ increase in lactational milk yield and a $30 \%$ increase in lactational milk fat yield in cows treated with sodium salicylate immediately postcalving. These 

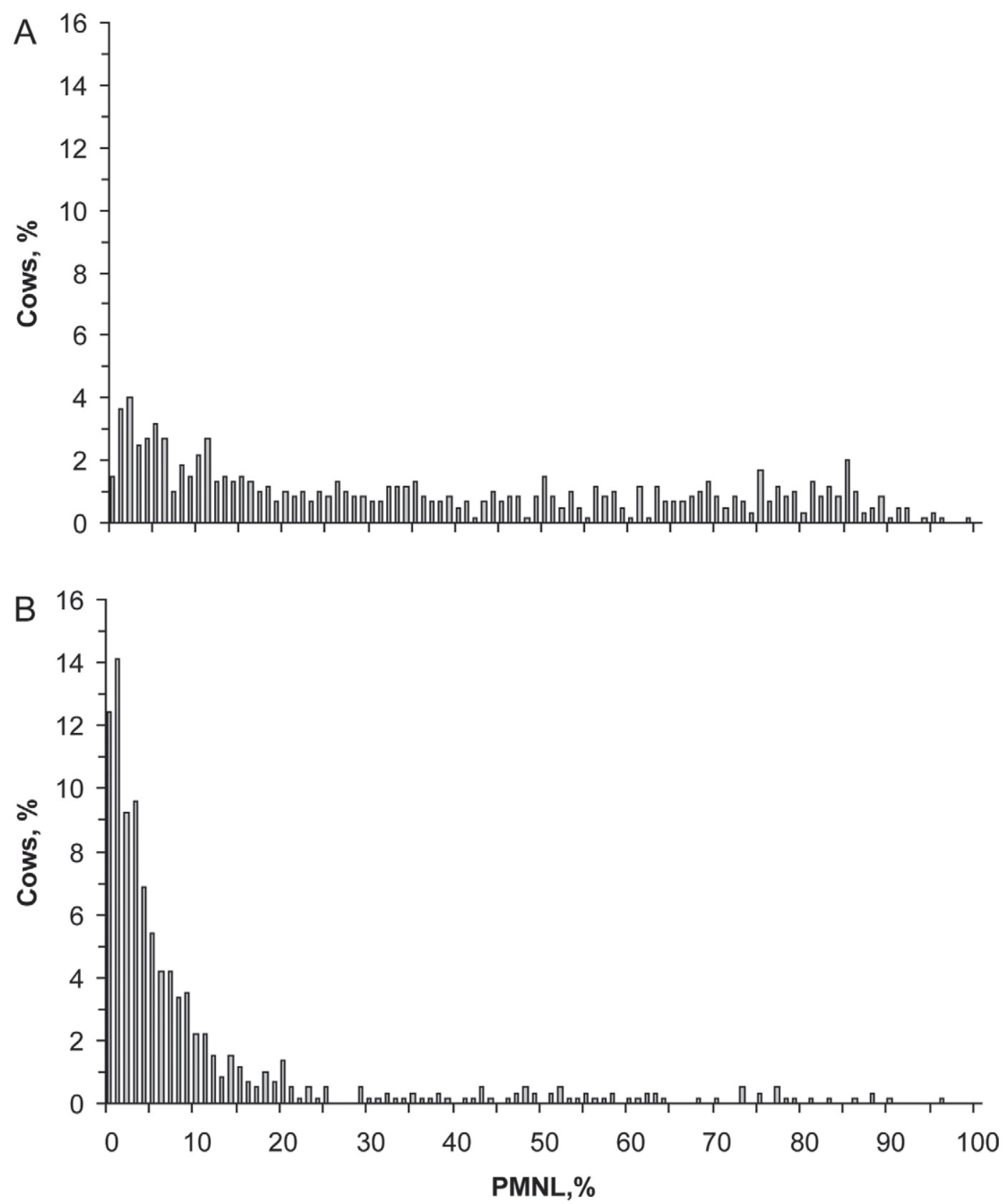

Figure 3. Polymorphonuclear neutrophilic leukocyte percentage distribution in uterine cytology samples from dairy cows at (A) 13 to 24 and (B) 30 to $49 \mathrm{~d}$ postcalving.

effects were parity dependent, with younger cows not increasing production with NSAID treatment and being at an increased risk of leaving the herd following treatment. These results indicate a sustained effect of NSAID on cow physiology and, possibly, a requirement for controlled inflammation in younger cows to avoid metabolic disturbances that influences their longevity. In comparison, no interaction existed between NSAID treatment and age group in the current experiment.

\section{Uterine Health and Reproduction}

No effect of treatment on either the vaginal mucus score (Metricheck score; Figure 2) or the PMNL percentage in the uterine cytological examination (Table 4) was detected. The distribution of PMNL percentage in uterine cytology is presented in Figure 3. Also, no effect existed of treatment on the proportion of cows classified by PMNL percentage threshold scores (Table 
Table 5. Percentage of untreated cows (control) or cows treated with a nonsteroidal antiinflammatory drug (1.4 $\mathrm{mg}$ of carprofen $/ \mathrm{kg}$ of BW) on d 1, 3, and 5 postcalving (early) or d 19,21, and 23 postcalving (late) that were classified as having subclinical endometritis by PMNL percentage thresholds ${ }^{1}$ on d 13 to 24 and d 30 to 49 postcalving

\begin{tabular}{lcccc}
\hline & \multicolumn{4}{c}{ Group based on PMNL thresholds ${ }^{2}$} \\
\cline { 2 - 5 } Treatment & High-high & High-low & Low-high & Low-low \\
\hline Control & 30 & 38 & 7 & 25 \\
Early & 30 & 35 & 11 & 24 \\
Late & 26 & 43 & 9 & 22 \\
\hline
\end{tabular}

${ }^{1}$ Thresholds for defining PMNL status (high or low): at 13 to $24 \mathrm{~d}$ postcalving, $\geq 14 \% \mathrm{PMNL}=$ high and $<14 \% \mathrm{PMNL}=$ low; at 30 to 49 d postcalving, $\geq 7 \%$ PMNL $=$ high and $<7 \%$ PMNL $=$ low.

${ }^{2}$ High-high means high 13 to $24 \mathrm{~d}$ postcalving and high 30 to $49 \mathrm{~d}$ postcalving; high-low means high 13 to 24 d postcalving and low 30 to $49 \mathrm{~d}$ postcalving; low-high means low 13 to $24 \mathrm{~d}$ postcalving and high 30 to $49 \mathrm{~d}$ postcalving; low-low means low 13 to $24 \mathrm{~d}$ postcalving and low 30 to $49 \mathrm{~d}$ postcalving.

5). The lack of effect of NSAID administration $3 \mathrm{wk}$ postcalving on uterine PMNL percentage is consistent with earlier results using the same NSAID (Priest et al., 2013), although a greater proportion of cows was categorized as high PMNL in the current study. Collectively, these data point to a lack of efficacy of the chosen NSAID in overcoming endometrial inflammation, irrespective of timing of delivery.

Administering an NSAID did not affect conception or pregnancy rates (Figure 4; Table 4), irrespective of the timing of delivery or the PMNL percentage status of the group. These results differ from those reported by Priest et al. (2013), who reported that the same NSAID increased pregnancy rate in cows identified with high PMNL percentage before administration. Interestingly, however, NSAID administration increased the proportion of cows submitted for breeding during the first 3 wk of the seasonal breeding period when administered at 3 wk postcalving, but not when administered during the $5 \mathrm{~d}$ immediately following calving (Table 6). Considering the reported negative effect of NSAID on ovulation in mammals (Murdoch et al., 1993; Sirois et al., 2004; Gaytán et al., 2006), the difference between early and late NSAID treatment could reflect a real effect of timing of administration. Burke et al. (2010b) and Green et al. (2011) reported a delay in ovulation in cows with SCE; the former study indicated no effect of SCE in the proportion of cows ovulated by 21 DIM, but with the effect of SCE becoming apparent and increasing from 35 DIM. It is plausible, therefore, that the early NSAID treatment was too early to elicit a beneficial effect on ovulation, whereas the late NSAID application was appropriately timed to improve ovulation in cows that had not yet cycled.

A further plausible reason for the effect of timing of NSAID administration on the detection of cows in

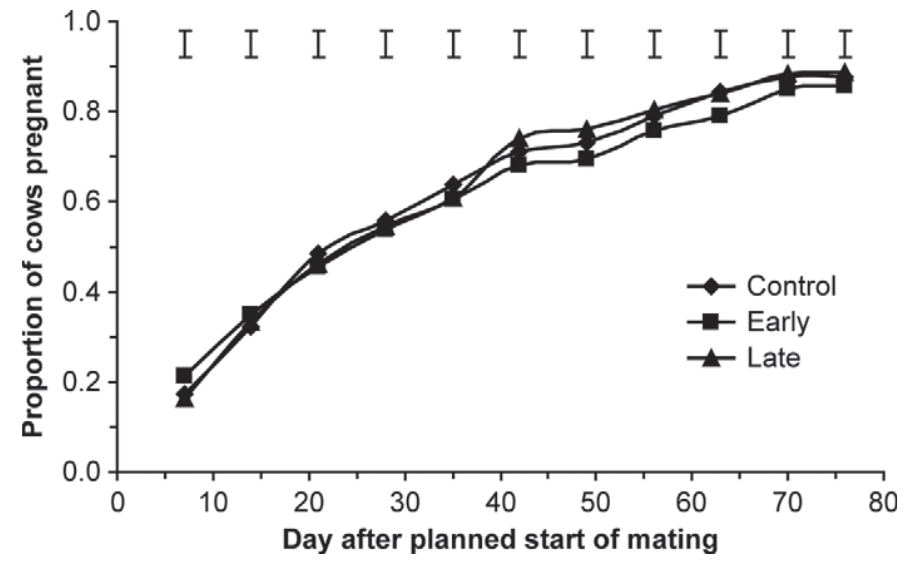

Figure 4. Proportion of cows that were pregnant (d 0 is planned start of mating in a seasonal calving system) if left untreated (control) or treated with a nonsteroidal antiinflammatory drug $(1.4 \mathrm{mg}$ of carprofen $/ \mathrm{kg}$ of BW) on d 1,3 , and 5 postcalving (early) or d 19,21, and 23 postcalving (late). Vertical bars represent $2 \times \mathrm{SE}$ of the difference.

estrus during the first 3 wk of the seasonal breeding period may be through a lowering of glucose and insulin concentrations in the early NSAID treatment. Offering insulinogenic diets in early lactation has been reported to increase LH pulsatility and reduce the postpartum anovulatory interval in both TMR-fed (Gong et al., 2002; Garnsworthy et al., 2008) and grazing (Burke et al., 2010a) dairy cows. In comparison, recent evidence from Farney et al. (2013a) highlighted a hypoglycemic and insulin-lowering effect of NSAID administration during the $5 \mathrm{~d}$ immediately postpartum. Such an effect would be expected to delay ovulation and may have counteracted any positive effect of NSAID administration on postpartum anovulatory interval in the early NSAID cows, if such an effect existed as was evident in the late NSAID treatment. Unfortunately, glucose and insulin were not measured in the current study.

In conclusion, NSAID administration to grazing cows in early lactation did not affect pregnancy rate

Table 6. Submission rate (SR; \%), conception rate (CR; \%), and pregnancy rate (PR; \%) of untreated cows (control) or those treated with a nonsteroidal antiinflammatory drug (1.4 mg of carprofen $/ \mathrm{kg}$ of BW) on d 1, 3, and 5 postcalving (early) or d 19,21, and 23 postcalving (late)

\begin{tabular}{lcccrr}
\hline & \multicolumn{3}{c}{ Treatment } & & \\
\cline { 2 - 4 } Parameter & Control & Early & Late & SED $^{1}$ & $P$-value \\
\hline 3-wk SR & 84.9 & 83.2 & 91.9 & 3.18 & $<0.05$ \\
3-wk CR & 55.4 & 52.8 & 50.4 & 5.33 & 0.64 \\
6-wk CR & 67.7 & 67.8 & 67.3 & 4.80 & 0.99 \\
6-wk PR & 71.1 & 68.0 & 74.0 & 4.47 & 0.42 \\
Final PR & 87.8 & 85.5 & 88.7 & 3.34 & 0.63 \\
\hline
\end{tabular}

${ }^{1} \mathrm{SE}$ of the difference.

${ }^{2}$ After a mating period of $76 \mathrm{~d}$. 
in this study, irrespective of the timing of delivery of the NSAID. However, the increase in late NSAID cows submitted to AI is consistent with a positive effect of NSAID administration 20 to 30 DIM on fertility outcomes as previously reported by Priest et al. (2013). Further research is required to understand in what situations NSAID administration will improve reproduction.

\section{Inconsistency of NSAID Effects}

The reason for the inconsistency in results between studies may reflect differences in the NSAID used in the experiments, differences in the effectiveness of doses used, or, potentially, differences in the lactational metabolic demand experienced by the cows in the different studies. Cows in the present experiment produced 0.96 $\mathrm{kg}$ of milk fat and $0.75 \mathrm{~kg}$ of milk protein/d; Priest et al. (2013) reported milk fat and protein yields of 0.86 and $0.66 \mathrm{~kg} / \mathrm{d}$, respectively; Farney et al. (2013b) reported that cows produced $1.90 \mathrm{~kg}$ of milk fat $/ \mathrm{d}$ and $1.27 \mathrm{~kg}$ of protein $/ \mathrm{d}$. Another possible reason for the failure of treatment to elicit a positive response on production or metabolic function is the duration of the experiment. It is possible that, had the experimental measurements continued for longer, positive effects of treatment on milk production may have occurred. Farney et al. (2013b) reported persistent, long-term effects of NSAID treatment that may not be determined in a short-term experiment. Further research is required to determine the effectiveness of different NSAID compounds, different doses of NSAID, and the interaction with metabolic stress.

\section{CONCLUSIONS}

Administering carprofen either in the days immediately following parturition or after 3 wk postcalving did not affect milk production, indicators of metabolic health, or most measures of reproduction in moderateyielding grazing dairy cows. Considering the positive and long-term effects of salicylic acid-derived NSAID in other studies, further research is required to evaluate the type of NSAID and its mode of action, the administration dose, and the timing of application in different production systems and with different cow genetics, as peripartum inflammation may be metabolically advantageous in the high-yielding dairy cow.

\section{ACKNOWLEDGMENTS}

The authors thank Fonterra and Matt Butler and the farm staff at Whareroa Farm (Hawera, New Zealand), Jacquie Buhler (DairyNZ, Westpac Trust Whareroa
Research Centre), and the DairyNZ (Hamilton, New Zealand) technicians involved with sample and data collection. Barbara Dow (DairyNZ) completed the statistical analyses. This research was supported by New Zealand dairy farmers through DairyNZ Inc. (AN808, AN1202), and the Ministry of Business, Innovation and Employment (Wellington, New Zealand; UOAX0814, DRCX1201).

\section{REFERENCES}

Bell, A. W. 1995. Regulation of organic nutrient metabolism during transition from late pregnancy to early lactation. J. Anim. Sci. 73:2804-2819

Bertoni, G., E. Trevisi, X. Han, and M. Bionaz. 2008. Effects of inflammatory conditions on liver activity in puerperium period and consequences for performance in dairy cows. J. Dairy Sci. 91:3300-3310.

Bertoni, G., E. Trevisi, and F. Piccioli-Cappelli. 2004. Effects of acetyl-salicylate used in post-calving of dairy cows. Vet. Res. Commun. 28:217-219.

Bradford, B. J., and J. K. Farney. 2010. Influence of inflammation on metabolism in transition cows. Pages 65-76 in Proc. 25th Ann. South-West Nutr. Management Conf., Tempe, AZ. The University of Arizona, Tucson.

Burke, C. R., J. K. Kay, C. V. C. Phyn, S. Meier, J. M. Lee, and J. R. Roche. 2010a. Short communication: Effects of dietary nonstructural carbohydrates pre- and postpartum on reproduction of grazing dairy cows. J. Dairy Sci. 93:4292-4296.

Burke, C. R., S. Meier, S. McDougall, C. Compton, M. Mitchell, and J. R. Roche. 2010b. Relationships between endometritis and metabolic state during the transition period in pasture-grazed dairy cows. J. Dairy Sci. 93:5363-5373.

Chagas, L. M., M. C. Lucy, P. J. Back, D. Blache, J. M. Lee, P. J. Gore, A. J. Sheahan, and J. R. Roche. 2009. Insulin resistance in divergent strains of Holstein-Friesian dairy cows offered fresh pasture and increasing amounts of concentrate in early lactation. J. Dairy Sci. 92:216-222.

De Koster, J. D., and G. Opsomer. 2013. Insulin resistance in dairy cows. Vet. Clin. North Am. Food Anim. Pract. 29:299-322.

Drackley, J. K. 1999. ADSA Foundation Scholar Award. Biology of dairy cows during the transition period: The final frontier? J. Dairy Sci. 82:2259-2273.

Drackley, J. K., H. M. Dann, G. N. Douglas, N. A. Janovick Guretzky, N. B. Litherland, J. P. Underwood, and J. J. Loor. 2005. Physiological and pathological adaptations in dairy cows that may increase susceptibility to periparturient diseases and disorders. Ital. J. Anim. Sci. 4:323-344.

Farney, J. K., L. K. Mamedova, J. F. Coetzee, B. Kukanich, L. M. Sordillo, S. K. Stoakes, J. E. Minton, L. C. Hollis, and B. J. Bradford. 2013a. Anti-inflammatory salicylate treatment alters the metabolic adaptations to lactation in dairy cattle. Am. J. Physiol. Regul. Integr. Comp. Physiol. 305:R110-R117.

Farney, J. K., L. K. Mamedova, J. F. Coetzee, J. E. Minton, L. C. Hollis, and B. J. Bradford. 2013b. Sodium salicylate treatment in early lactation increases whole-lactation milk and milk fat yield in mature dairy cows. J. Dairy Sci. 96:7709-7718. http://dx.doi. org/10.3168/jds.2013-7088.

Garnsworthy, P. C., K. D. Sinclair, and R. Webb. 2008. Integration of physiological mechanisms that influence fertility in dairy cows. Animal 2:1144-1152.

Gaytán, M., C. Morales, C. Bellido, J. E. Sánchez-Criado, and F. Gaytán. 2006. Non-steroidal anti-inflammatory drugs (NSAIDs) and ovulation: Lessons from morphology. Histol. Histopathol. $21: 541-556$.

Gong, J. G., W. J. Lee, P. C. Garnsworthy, and R. Webb. 2002. Effect of dietary-induced increases in circulating insulin concentrations 
during the early postpartum period on reproductive function in dairy cows. Reproduction 123:419-427.

Green, M. P., A. M. Ledgard, S. E. Beaumont, M. C. Berg, K. P. McNatty, A. J. Peterson, and P. J. Back. 2011. Long-term alteration of follicular steroid concentrations in relation to subclinical endometritis in postpartum dairy cows. J. Anim. Sci. 89:3551-3560.

Hayirli, A. 2006. The role of exogenous insulin in the complex of hepatic lipidosis and ketosis associated with insulin resistance phenomenon in postpartum dairy cattle. Vet. Res. Commun. 30:749-774.

Huzzey, J. M., T. F. Duffield, S. J. LeBlanc, D. M. Veira, D. M. Weary, and M. A. G. von Keyserlingk. 2009. Short communication: Haptoglobin as an early indicator of metritis. J. Dairy Sci. 92:621-625.

Huzzey, J. M., D. M. Veira, D. M. Weary, and M. A. G. von Keyserlingk. 2007. Prepartum behavior and dry matter intake identify dairy cows at risk for metritis. J. Dairy Sci. 90:3220-3233.

Ingvartsen, K. L. 2006. Feeding- and management-related diseases in the transition cow: Physiological adaptations around calving and strategies to reduce feeding-related diseases. Anim. Feed Sci. Technol. 126:175-213.

Jiang, H., M. C. Lucy, B. A. Crooker, and W. E. Beal. 2005. Expression of growth hormone receptor 1A mRNA is decreased in dairy cows but not in beef cows at parturition. J. Dairy Sci. 88:1370-1377.

LeBlanc, S. 2010. Monitoring metabolic health of dairy cattle in the transition period. J. Reprod. Dev. 56(Suppl.):S29-S35.

Lucy, M. C., G. A. Verkerk, B. E. Whyte, K. A. Macdonald, L. Burton, R. T. Cursons, J. R. Roche, and C. W. Holmes. 2009. Somatotropic axis components and nutrient partitioning in genetically diverse dairy cows managed under different feed allowances in a pasture system. J. Dairy Sci. 92:526-539.

McDougall, S., H. Hussein, D. Aberdein, K. Buckle, J. Roche, C. Burke, M. Mitchell, and S. Meier. 2011. Relationships between cytology, bacteriology and vaginal discharge scores and reproductive performance in dairy cattle. Theriogenology 76:229-240.

McDougall, S., R. Macaulay, and C. Compton. 2007. Association between endometritis diagnosis using a novel intravaginal device and reproductive performance in dairy cattle. Anim. Reprod. Sci. 99:9-23.

Ministry for Primary Industries. 1999. Part 6. Use of animals in research, testing and teaching. In New Zealand Animal Welfare Act. Ministry for Primary Industries, Wellington, New Zealand.

Murdoch, W. J., T. R. Hansen, and L. A. McPherson. 1993. A review-Role of eicosanoids in vertebrate ovulation. Prostaglandins $46: 85-115$.

Overton, T. R., and M. R. Waldron. 2004. Nutritional management of transition dairy cows: Strategies to optimize metabolic health. J. Dairy Sci. 87(E. Suppl.):E105-E119.
Payne, R. W., D. A. Murray, S. A. Harding, D. B. Baird, and D. M. Soutar. 2011. An Introduction to GenStat for Windows. 14th ed. VSN International Ltd., Hemel Hempstead, UK.

Priest, N. V., K. L. McLeod, S. McDougall, C. R. Burke, J. R. Roche, M. D. Mitchell, S. L. Greenwood, and S. Meier. 2013. The responsiveness of subclinical endometritis to a nonsteroidal antiinflammatory drug in pasture-grazed dairy cows. J. Dairy Sci. 96:4323-4332.

Roche, J. R., P. G. Dillon, C. R. Stockdale, L. H. Baumgard, and M. J. VanBaale. 2004. Relationships among international body condition scoring systems. J. Dairy Sci. 87:3076-3079.

Roche, J. R., N. C. Friggens, J. K. Kay, M. W. Fisher, K. J. Stafford, and D. P. Berry. 2009. Invited review: Body condition score and its association with dairy cow productivity, health, and welfare. J. Dairy Sci. 92:5769-5801.

Roche, J. R., E. S. Kolver, and J. K. Kay. 2005. Influence of precalving feed allowance on periparturient metabolic and hormonal responses and milk production in grazing dairy cows. J. Dairy Sci. $88: 677-689$.

Roche, J. R., K. A. Macdonald, K. E. Schutz, L. R. Matthews, G. A. Verkerk, S. Meier, J. J. Loor, A. R. Rogers, J. McGowan, S. R. Morgan, S. Taukiri, and J. R. Webster. 2013. Calving body condition score affects indicators of health in grazing dairy cows. J. Dairy Sci. 96:5811-5825.

Sirois, J., K. Sayasith, K. A. Brown, A. E. Stock, N. Bouchard, and M. Doré. 2004. Cyclooxygenase-2 and its role in ovulation: A 2004 account. Hum. Reprod. Update 10:373-385.

Trevisi, E., and G. Bertoni. 2008. Attenuation of acetylsalicylate treatments of inflammatory conditions in periparturient dairy cows. Pages 23-37 in Aspirin and Health Research Progress. P. I. Quinn, ed. Nova Science Publishers, New York, NY.

Uribe, H. A., B. W. Kennedy, S. W. Martin, and D. F. Kelton. 1995. Genetic parameters for common health disorders of Holstein cows. J. Dairy Sci. 78:421-430.

Vangroenweghe, F., L. Duchateau, P. Boutet, P. Lekeux, P. Rainard, M. J. Paape, and C. Burvenich. 2005. Effect of carprofen treatment following experimentally induced Escherichia coli mastitis in primiparous cows. J. Dairy Sci. 88:2361-2376.

Zachut, M., H. Honig, S. Striem, Y. Zick, S. Boura-Halfon, and U. Moallem. 2013. Periparturient dairy cows do not exhibit hepatic insulin resistance, yet adipose-specific insulin resistance occurs in cows prone to high weight loss. J. Dairy Sci. 96:5656-5669. 